\title{
EXOTIC PALMS THREATENS NATIVE PALMS: A RISK TO PLANT BIODIVERSITY OF ATLANTIC FOREST ${ }^{1}$
}

Tiago Monteiro Condée ${ }^{*}$, Fernando da Silva ${ }^{3}$, Agostinho Lopes de Souza ${ }^{4}$, Helio Garcia Leite ${ }^{4}$, Eder Aparecido Garcia ${ }^{5}$, Walter da Silva Costa ${ }^{6}$, Antonio de Souza Chaves ${ }^{7}$ and Pablo Falco Lopes ${ }^{7}$

\footnotetext{
${ }^{1}$ Received on 13.12.2016 accepted for publication on 05.03.2018.

${ }^{2}$ Universidade Estadual de Roraima, Departamento de Engenharia Florestal, Rorainópolis, RR-Brasil. E-mail: <tiagonafloresta@gmail.com>.

${ }^{3}$ Universidade Federal do Mato Grosso, Instituto de Ciências Agrárias e Ambientais, MT-Brasil. E-mail: <silvaflorestal@gmail.com>.

${ }^{4}$ Universidade Federal de Viçosa, Departamento de Engenharia Florestal, Viçosa, MG-Brasil. E-mail: <hgleite@gmail.com> and<alsouzaal@gmail.com>.

${ }^{5}$ Centro Estadual de Educação Tecnológica Paula Souza, Curso Superior de Tecnologia em Agronegócio, Ourinhos, SP-Brasil. E-mail: <garcia.florestal@gmail.com>.

${ }^{6}$ Consultoria Florestal, Ipatinga, MG-Brasil. E-mail: <walterfloresteiro@hotmail.com>.

${ }^{7}$ DAP Engenharia Florestal Ltda, Viçosa, MG-Brasil.E-mail: <ascengenheiroflorestal@gmail.com>and <pfalcol@dapflorestal.com.br>.

*Corresponding author.
}

\begin{abstract}
Invasive plants can profoundly modify physical and biological characteristics of their new environments, especially when such habitats are already fragmented and reduced by anthropogenic pressure, such as the Atlantic Forest of Brazil. Here, we hypothesized that exotic palms successfully establish among the natural Euterpe edulis populations through a continuous propagule input by avifauna, high germination rates, and rapid growth. As a result, the native palm is experiencing decline and may be threatened with extinction. Beginning in 2007, we conducted a continuous forest inventory (FCI) every three years in the primary and secondary forest fragments of Viçosa, Minas Gerais. We use a Markov matrix to project future distributions of palm trees. The secondary forest contained three exotic palm species: Archontophoenix alexandrae, Livistona chinensis, and Arenga caudata. The first palm is a serious risk to natural E. edulis populations in the Atlantic because of frequent interactions with birds, rapid germination, and aggressive colonization in the lower to medium vertical forest strata. Currently, natural E. edulis populations are viable and sustainable, capable of regeneration, growth, and fruiting, their communities maintain continuous gene flow, dominating vertical forest strata compared with exotic palms. However, exotic palms should be monitored and control measures should be analyzed, especially in areas with A. alexandrae populations.
\end{abstract}

Keywords: Archontophoenix alexandrae; Biological invasion; Euterpe edulis.

\section{PALMEIRAS EXÓTICAS AMEAÇAM PALMEIRAS NATIVAS: RISCO PARA A BIODIVERSIDADE VEGETAL DA MATA ATLÂNTICA}

\begin{abstract}
RESUMO - As plantas invasoras podem modificar profundamente as características físicas e biológicas de seus novos ambientes, especialmente quando esses habitats já estão fragmentados e reduzidos pela pressão antropogênica, como a Mata Atlântica do Brasil. Aqui, nós hipotetizamos que as palmeiras exóticas se estabelecem com sucesso entre as populações naturais de Euterpe edulis através de entrada contínua de propágulos pela avifauna, altas taxas de germinação e rápido crescimento. Como resultado, a palmeira nativa está sofrendo declínio e pode estar ameaçada de extinção. A partir de 2007, realizamos um inventário florestal contínuo (FCI) a cada três anos nos fragmentos florestais primários e secundários de Viçosa, Minas Gerais. Usamos uma matriz de Markov para projetar futuras distribuições de palmeiras. A floresta secundária continha três espécies de palmeiras exóticas: Archontophoenix alexandrae, Livistona chinensis e Arenga caudata. A primeira palmeira é um sério risco para as populações naturais de E. edulis na Mata Atlântica, devido às interações freqüentes com as aves, à rápida germinação e à colonização agressiva nos estratos verticais inferior e médio
\end{abstract}


da floresta. Atualmente, as populações naturais de E. edulis são viáveis e sustentáveis, capazes de regeneração, crescimento e frutificação, pois suas comunidades mantêm o fluxo gênico contínuo, dominando os estratos verticais da floresta em comparação com as palmeiras exóticas. No entanto, palmeiras exóticas devem ser monitoradas e medidas de controle devem ser analisadas, especialmente em áreas com populações de A. alexandrae.

Palavras-Chave: Archontophoenix alexandrae, Euterpe edulis, Invasão biológica.

\section{INTRODUCTION}

The Atlantic Forest is among 25 critical biodiversity points worldwide (Cincotta et al., 2000). Threatened by land use changes and decreasing land cover (SoaresFilho et al., 2014), only $12.5 \%$ of the original forest area remains (SOSMA/INPE, 2014). The Atlantic Forest comprises ecosystems that have lost $70 \%$ of their original vegetation but together still possess more of $60 \%$ of all terrestrial species on the planet (Chediack and Baqueiro, 2005). Much of the current forest is extremely fragmented by human activity and located within cities (Gastauer et al., 2015). Furthermore, approval of the new Brazilian Forest Code (2012) increased the vulnerability of these regions (Soares-Filho et al., 2014).

Along with fragmentation effects, the invasion of exotic species has led to plant biodiversity big losses in Atlantic Forest remnants (Christianini, 2006). Biodiversity loss begins with reduced environmental and genetic variability (along with any interactions), eventually culminating in local extinction (Santos et al., 2016). Through competitive exclusion, invasive terrestrial plants can profoundly modify the physical and biological characteristics of their surroundings (D'Antonio and Vitousek, 1992), altering soil properties, shading, primary productivity, and susceptibility to fire (Christianini, 2006; Mengardo and Pivello, 2012).

During the $21^{\text {st }}$ century, the Portuguese royal family introduced exotic palm trees to Rio de Janeiro for use in gardens and botanical parks (Araujo and Silva, 2010). Avifaunal seed dispersal subsequently facilitated establishment in native ecosystems (Chapple et al., 2012; Almeida et al., 2015). The negative effects of biological invasions on local biodiversity can occur through multiple levels, altering individuals in a community, genetics, population dynamics, and ecosystem processes (Parker et al., 1999; van Wilgen and Richardson, 2014). Among exotic and invasive palms in Brazil, the genus Archontophoenix exerts a particularly strong impact on natural Juçara or açaí palm (Euterpe edulis M.) populations in the Atlantic Forest (Dislich et al., 2002; Christianini, 2006).
Euterpe edulis prefers humid regions and is native to the Atlantic Forest and Cerrado. Exclusively seedpropagated, they provide food for Cracidae (Penelope ochrogaster and Aburria cumanensis); Ramphastidae (Ramphastos toco), Cotingidae (Procnias nudicollis); Turdidae (Turdus rufiventris); Tynannidae (Pitangus sulphuratus); and mammals including rodents, marsupials, primates, and even bats (Martins and Lima, 1999). The palm's colonization strategy is heavily dependent on avifauna (Fantini and Guries, 2007). The status of E. edulis is considered indicative of conservation effort devoted to a given forest fragment. Predatory illegal exploitation (Orlande et al., 1995), coupled with deforestation and fragmentation, devastated natural E. edulis populations and caused a decline in palm-heart production during the 1960s (Cervi, 1996; Carvalho et al., 2015; Santos et al., 2016).

Identifying illegal extraction is extremely difficult (Galetti and Fernandez, 1998), because exploitation is selective and undetectable via Landsat satellite images (Asner et al., 2005). During the past decade, E. edulis was declared a species at risk of extinction in Argentina and vulnerable in Brazil and Paraguay (Chediack and Baqueiro, 2005). In this study, we hypothesized that E. edulis decline and extinction risk is closely tied to the establishment of exotic palm trees through continuous avifauna-promoted propagule entry, high germination, and rapid growth.

\section{MATERIALAND METHODS}

\subsection{Study area}

The study area comprises two forest fragments of semidecidual seasonal mountain forest in Viçosa, Minas Gerais, Brazil. The first area (A1) is a secondary forest fragment of 75 ha, located at the University Federal of Viçosa (UFV) (204’2 00’3 S; 42 51'2 00’3 W). Deforested in 1922 for coffee planting, area A1 is currently in the process of natural regeneration. The second area (A2) is a preserved (Gastauer et al., 2015) primary forest fragment of 36 ha ( $20^{\circ} 47^{\prime} 2$ 43'” 3 S; 42 $50^{\prime} 2$

Revista Árvore. 2018;42(2):e420216 
47’3 W) on a private rural property, used as control (Figure 1). The municipality encompassing both forests fragments with 620-820 m in altitude, intersected by Doce River tributaries and exhibiting a highly mountainous topography. Red and red-yellow Oxisols dominate the region. The climate is humid subtropical wetland, with rainy summers and cold, dry winters (Ferreira Júnior et al., 2007).

\subsection{Data collection}

We performed continuous forest inventory (CFI) every three years starting from 2007 until 2013, to evaluate forest dynamics of exotic palm invasion into natural E. edulis populations. Each forest fragment (A1 and A2) contained five randomly distributed, permanent plots $\left(10 \times 25 \mathrm{~m}, 250 \mathrm{~m}^{2}\right)$, totaling a sampled area of 0.25 ha. Two types of data were collected. Level I included all palm trees with diameter at breast height (DBH) $\geq 5.0 \mathrm{~cm}$, preferably measured at $1.30 \mathrm{~m}$ from the soil. A Vertex IV hypsometer (Haglöf Sweden) was used to estimate total height $(\mathrm{H})$ of palms. Level II involved the A 1 fragment only; 10 randomly placed subplots $\left(1 \mathrm{~m}^{2}\right)$ were first designated within each plot (50 subplots
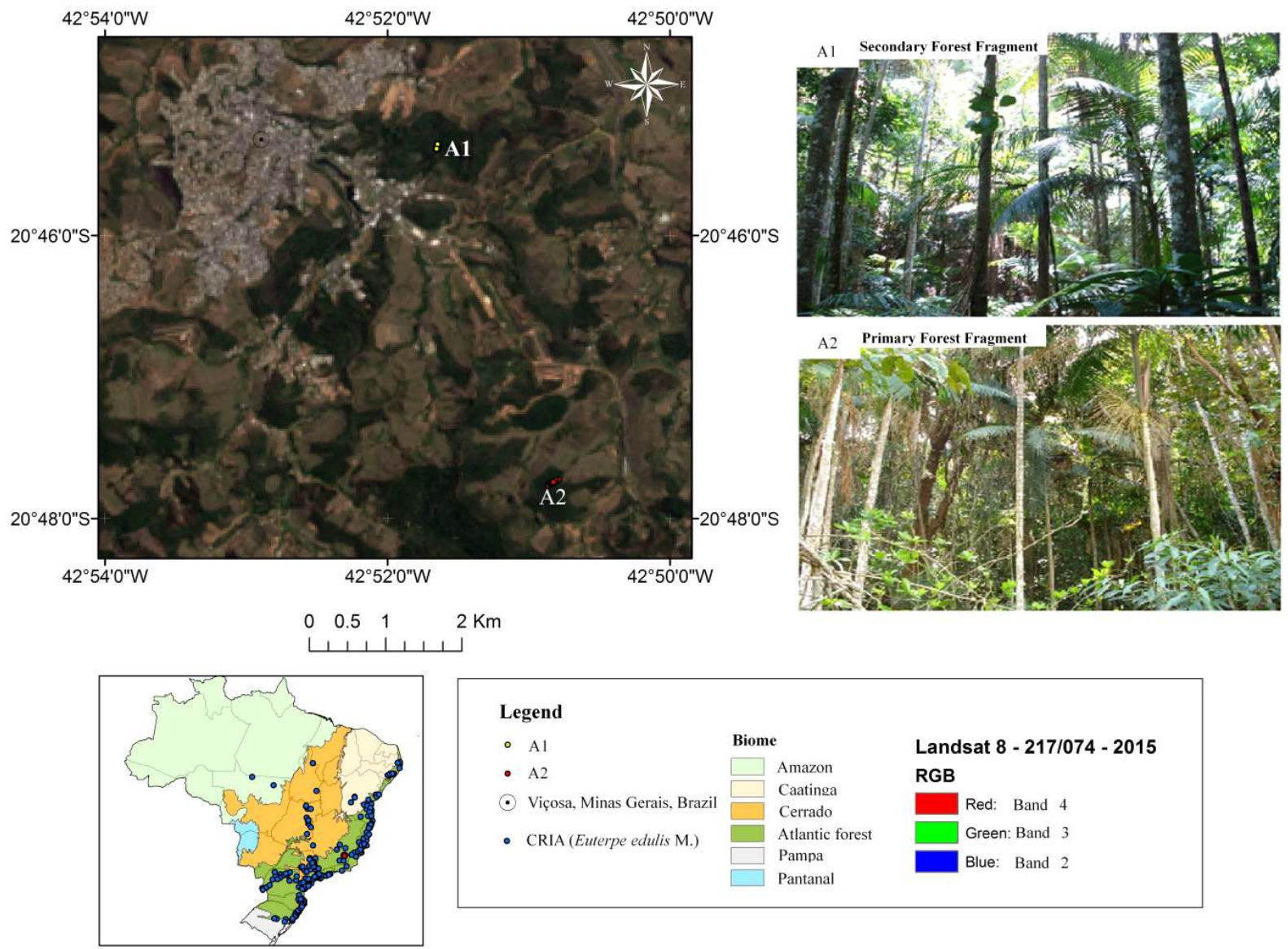

Figure 1 - Location of study areas. Photographs show the two study fragments. Yellow points are palms in the secondary forest fragment (A1) and red points are palms in the primary forest fragment (A2). Blue points are E. edulis records from CRIA (http://www.splink.org.br).

Figura 1 - Localização das áreas de estudo. Fotos do interior dos dois fragmentos estudados. Pontos amarelos são palmeiras do fragmento secundário (A1) e pontos vermelhos do fragmento primário (A2). Pontos azuis são registros de E. edulis do CRIA (http://www.splink.org.br). 
total), and then all palm seedlings with circumference at ground level $(C G L) \leq 10 \mathrm{~cm}$ were measured.

During CFI, plants were identified with the support of the Forest Engineering Department at UFV. A sample from each species was then collected and sent to the Botany Herbarium at UFV. Updates to any scientific names were performed at Tropicos (http:// www.tropicos.org/), and species were classified by the Angiosperm Phylogeny Group III.

\subsection{Data analysis}

Forest vertical structure was analyzed across three levels (Condé and Tonini, 2013): Lower Stratum (LS), palm trees with $H<(\bar{H}-1 \sigma)$; Middle Stratum (MS), palm trees with $(\overline{\mathrm{H}}-1 \sigma) \leq \mathrm{H}<(\overline{\mathrm{H}}-1 \sigma)$; Superior Stratum (SS), palm trees with $H \geq(\overline{\mathrm{H}}-1 \sigma)$, where $(\overline{\mathrm{H}})=$ average and $\sigma=$ standard deviation of total height. Rate of change (C) in population density and regeneration frequency in the CFI during 2007-2013 were calculated following Souza and Soares (2013). Invasion dynamics during 2007-2013 were analyzed to predict 2016 conditions in A1 using the Markov matrix, after adaptation of the Buongiorno and Michie model (1980):

$$
Y_{n \theta}=G_{\theta} \cdot Y_{(n-1) \theta}+R_{t \times \theta}-M_{t \times \theta}
$$

where $Y_{n \theta}=$ column vector of tree count by diameter class, after $n$ time periods; $\mathrm{G}_{\theta}=$ Markov matrix of the first period (2007-2010); $\mathrm{Y}_{(\mathrm{n}-1) \theta}=$ column vector of tree count by diameter class, earlier in $\mathrm{n}$ time periods; $\mathrm{R}_{\mathrm{t} \mathrm{x} \theta}$ = column vector of ingrowth trees by diameter class in a given period, dependent on rate or probability of ingrowth (scenarios 1 or 2); $\mathrm{M}_{\mathrm{tx} \theta}=$ column vector of dead trees by diameter class in a given period, dependent on rate or likelihood of death (scenarios 1 or 2$)$.

Column vectors of ingrowth and mortality were calculated with the following equations:

$$
\begin{aligned}
& R_{t x \theta}=\sum_{i=1}^{n}\left(\mathrm{~N}_{(n-1) \theta} \cdot\left(\frac{\mathrm{R}_{\theta}}{\mathrm{N}_{\theta}}\right)\right) \\
& M_{t x \theta}=\sum_{i=1}^{n}\left(\mathrm{~N}_{(n-1) \theta} \cdot\left(\frac{\mathrm{M}_{\theta}}{\mathrm{N}_{\theta}}\right)\right)
\end{aligned}
$$

Where $\mathrm{N}_{(\mathrm{n}-1) \theta}=$ living tree count by diameter class, earlier in $\mathrm{n}$ time periods; $\mathrm{N}_{\theta}=$ living tree count by class diameter, in a given periods; $\mathrm{R}_{\theta}=$ ingrowth count by tree diameter class in a given period; $\mathrm{M}_{\theta}=$ dead tree count by diameter class in a given period.

Predictions of exotic and native palm dynamics were made for four time intervals: 1) 2007-2010, 2) 2010 2013, 3) 2013-2016, 4º 2013-2021 (A1 only). Distribution frequencies of individuals per diameter class were compared using the chi-squared test. Significance was set to $\mathrm{p}<0.01$ and $\mathrm{p}<0.05$. In scenario 1 , frequencies were estimated with entry and mortality rates for 20072010. In scenario 2, frequencies were estimated with entry and mortality rates for 2010-2013. Statistical and graphical analyses were performed with Microsoft Excel 2007 and the "ggplot2” package in R (R Core Team, 2018).

\section{RESULTS}

In A1 during 2007, we measured E. edulis, Archontophoenix alexandrae H. Wendl. \& Drude, and Livistona chinensis (Jack.) R. Br. (latter two species are exotic). Density of individuals was highest for $E$. edulis (920 ind. ha ${ }^{-1}$ ). Species composition was unchanged in 2010, but the E. edulis population had decreased, while exotic populations remained stable. In 2013, we found an additional exotic palm, Arenga caudata (Lour.) H. E. Moore, while E. edulis population further declined and A. alexandrae population increased. In A2, exotic palm trees were not found during either CFI period (Table 1). Both $\mathrm{DBH}$ and $\mathrm{H}$ were higher in E. edulis of A2 than of A1. Additionally, the A2 E. edulis population increased by $2 \%$ from 2007 to 2010 but decreased by 6\% from 2010 to 2013 (Table 1).

Diameter growth (as measured by DBH) differed across the four palm species (Figure 2). Euterpe edulis and $A$. alexandrae were remained mainly in diameter classes 5-17 cm and 7-23 cm, respectively. The other exotic palms were low in density.

Vertical stratification of A1 palms resulted in LS $=\mathrm{H}<4.6 \mathrm{~m}$, MS $=4.6 \leq \mathrm{H}<14.4 \mathrm{~m}$, and SS $=\mathrm{H} \geq 14.4$ $\mathrm{m}$, with the highest being E. edulis (maximum $24.8 \mathrm{~m}$ ). The population of A. alexandrae maintained $93 \%$ of individuals in LS and MS during 2007-2013. From 2007 to 2010, E. edulis was dominant in MS, but A. alexandrae had taken over by 2013. In A2, LS $=\mathrm{H}<8.3 \mathrm{~m}$, MS $=8.3 \leq \mathrm{H}<18.5 \mathrm{~m}$, and $\mathrm{SS}=\mathrm{H} \geq 18.5 \mathrm{~m}$, with E. edulis reaching $25.8 \mathrm{~m}$.

Throughout the CFI (2007-2013) in A1,naturalregeneration seedling count (level II) was highest in E. edulis, but a $-75 \%$ rate of change revealed a large

Revista Árvore. 2018;42(2):e420216 
Table 1 - Dynamics of population density (PD), seedlings regeneration (R), diameter at breast height (DBH), and total height $(\mathrm{H})$ of exotic palms and E. edulis in two Atlantic Forest forests fragments from Viçosa, Minas Gerais, Brazil. A1 = secondary forest fragment; A2 = primary forest fragment. C = Rate of change $(\%)$. Values are means and standard deviation.

Tabela 1 - Dinâmica da densidade populacional (PD), regeneração de plântulas (R), diâmetro à altura do peito (DBH) e altura total $(H)$ de palmeiras exóticas e E. edulis em dois fragmentos florestais de Mata Atlântica em ViçosaMG, Brasil. $A 1$ = fragmento secundário; $A 2$ = fragmento primário. $C$ = taxa de mudança (\%). Valores referentes a média e desvio padrão.

\begin{tabular}{|c|c|c|c|c|c|c|c|c|c|c|c|c|c|c|c|}
\hline \multirow[t]{2}{*}{ Area } & \multirow[t]{2}{*}{ Species } & \multicolumn{3}{|c|}{ PD (ind. ha ${ }^{-1}$ ) } & \multirow{2}{*}{ C (\%)R } & \multicolumn{3}{|c|}{$($ seedlings ha-1) } & \multirow[t]{2}{*}{ C (\%) } & \multicolumn{3}{|c|}{$\mathrm{DBH}(\mathrm{cm})$} & \multicolumn{3}{|c|}{$\mathrm{H}(\mathrm{m})$} \\
\hline & & 2007 & 2010 & 2013 & & 2007 & 2010 & 2013 & & 2007 & 2010 & 2013 & 2007 & 2010 & 2013 \\
\hline \multirow[t]{3}{*}{$\mathrm{A} 2$} & E. edulis & 992 & 1,008 & 952 & -4 & - & - & - & - & $12.2 \pm 3.5$ & $12.2 \pm 3.6$ & $12.1 \pm 3.7$ & $12.7 \pm 4.8$ & $13.7 \pm 5.1$ & $14.0 \pm 5.3$ \\
\hline & E. edulis & 920 & 872 & 736 & -20 & 78,800 & 75,200 & 19,400 & -75 & $11.0 \pm 4.1$ & $11.4 \pm 4.0$ & $11.9 \pm 4.1$ & $10.9 \pm 4.3$ & $11.8 \pm 4.5$ & $13.2 \pm 5.1$ \\
\hline & A. alexandrae & 744 & 744 & 776 & +4 & 3,000 & 3,000 & 12,400 & +313 & $12.7 \pm 5.7$ & $13.7 \pm 6.0$ & $14.3 \pm 5.7$ & $5.7 \pm 3.2$ & $7.1 \pm 3.3$ & $7.7 \pm 3.8$ \\
\hline \multirow[t]{2}{*}{ A1 } & L. chinensis & 16 & 16 & 8 & -50 & 2,600 & 2,600 & 600 & -77 & $23.0 \pm 12.9$ & $33.2 \pm 11.6$ & $25.0 \pm 12.9$ & $6.0 \pm 2.1$ & $6.3 \pm 2.5$ & 4.5 \\
\hline & A. caudata & - & - & 8 & - & - & - & - & - & - & - & 5.6 & - & - & 4.0 \\
\hline
\end{tabular}
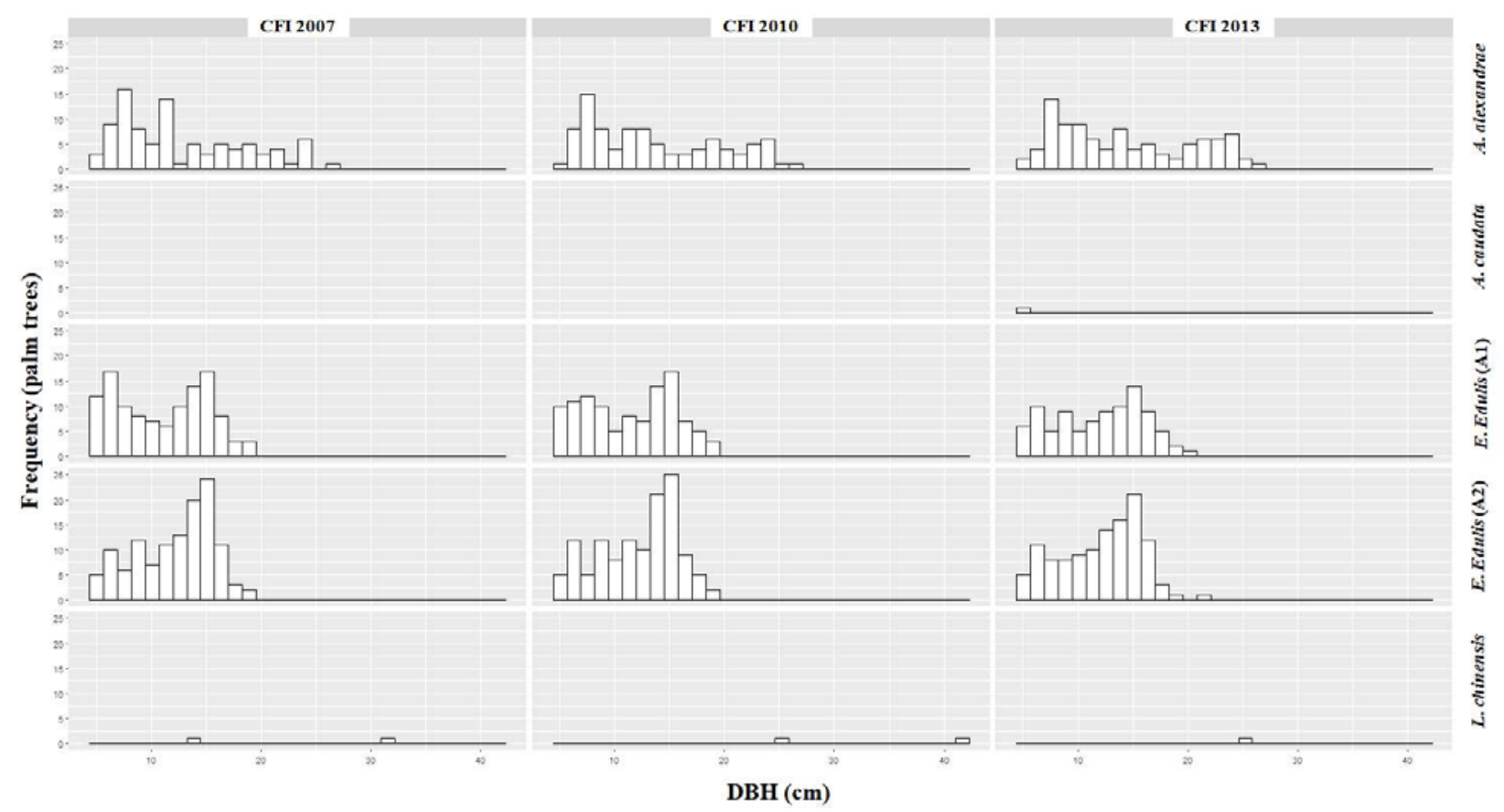

Figure 2 - Frequency by diameter class of three exotic palms (A. alexandrae, A. caudata, L. chinensis) and the native E. edulis based on CFI data (2007/2010/2013). A1 = secondary forest fragment; A2 = primary forest fragment.

Figura 2 - Frequência por classe de diâmetro de três palmeiras exóticas (A. alexandrae; A. caudata; L. chinensis) e a nativa E. edulis no IFC (2007/2010/2013). A1 = fragmento florestal secundário; A2 = fragmento florestal primário.

reduction in progress (Table 1 ). In contrast, A. alexandrae exhibited a $+300 \%$ rate of change, indicating substantial increase in regeneration. Livistona chinensis regeneration was also declining. In 2007-2010, 8\% of studied areas did not exhibit natural palm regeneration, but by 20102013, the amount had risen sharply to $22 \%$. Figure 3 depicts morphometry, regeneration, fruiting, and establishment data from $A$. alexandrae and $L$. chinensis within E. edulis populations of A1.
Due to reduced number of individuals registered for other exotic palm trees, we calculated transition matrices only for E. edulis and A. alexandrae in A1. In 2007-2010, E. edulis mortality rate (8\%) was higher than its ingrowth rate (3\%), while both rates were similar (1\%) for A. alexandrae. In 2010-2013, E. edulis mortality rate $(17 \%)$ was again higher than ingrowth rate $(1.1 \%)$, whereas A. alexandrae ingrowth rate (5\%) was higher than its mortality rate (1\%). Predicted population dynamics

Revista Árvore. 2018;42(2):e420216 


\section{Euterpe edulis}
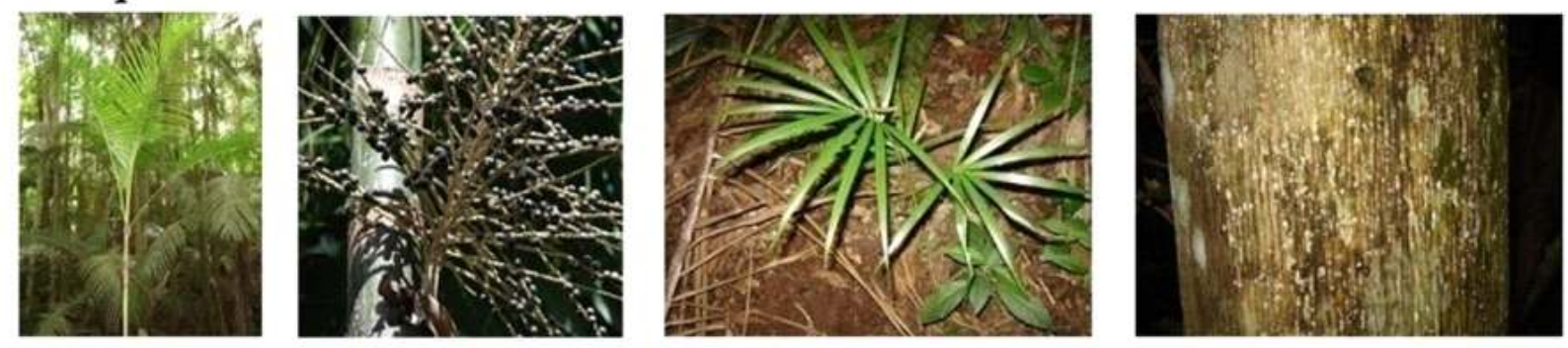

\section{Archontophoenix alexandrae}
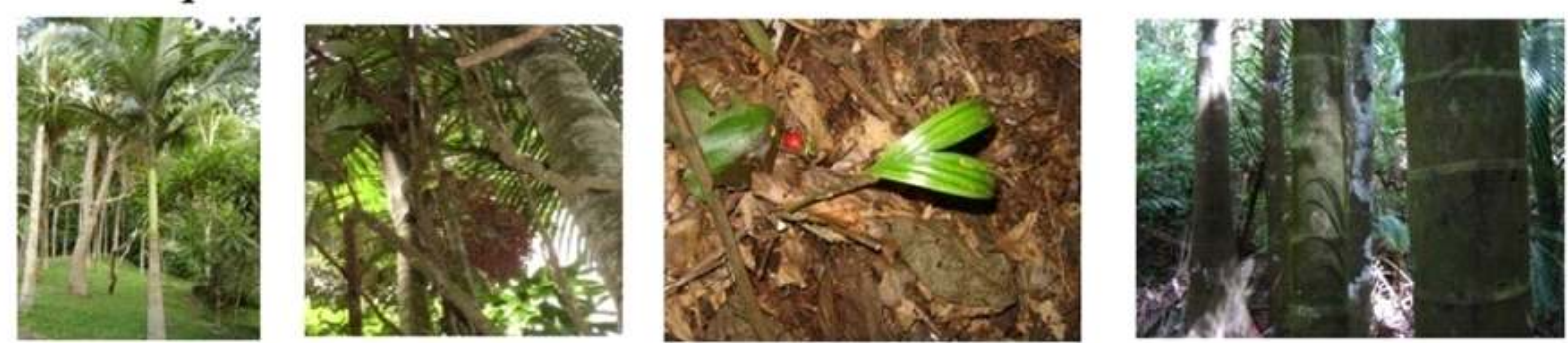

\section{Livistona chinensis}
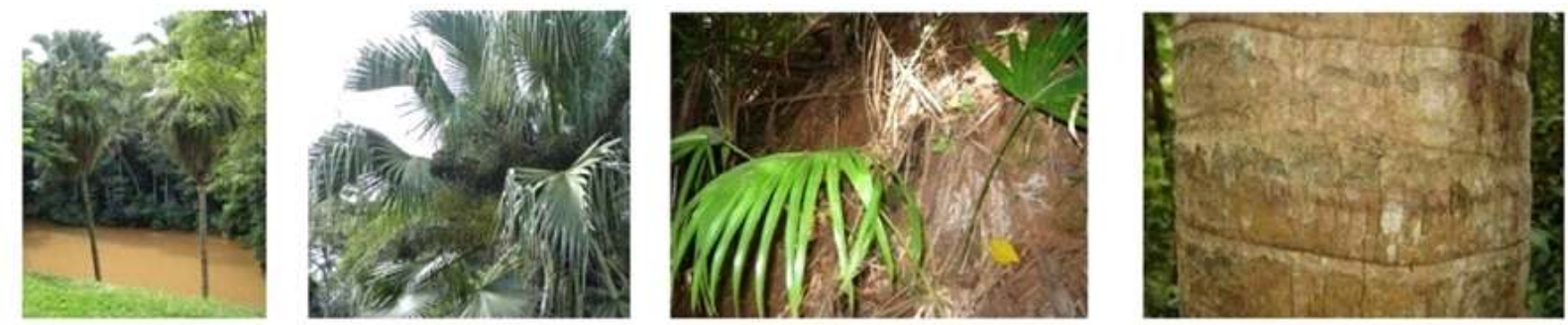

Figure 3 - Morphometry, fruiting, regeneration, and establishment within the secondary forest fragment (A1).

Figura 3 - Morfometria, frutificação, regeneração e estabelecimento de palmeiras ao entorno e dentro do fragmento florestal secundário (A1).

for E. edulis during 2007-2010 and 2010-2013 were statistically similar to observed frequencies (2007-2010: $\mathrm{p}>0.05, x^{2}=$ $1.2^{\text {not-significant (ns) }} ; 2010-2013: \mathrm{p}>0.05, x_{\text {scenario } 1}^{2}=6.7^{\text {ns }}$, $\left.x_{\text {scenario } 2}^{2}=9.9^{\text {ns }}, x^{2}{ }_{5 \%}=14.07, x^{2}{ }_{1 \%}=18.48\right)$ (Figures $4 \mathrm{~A}$, 4B). However, predicted frequencies in 2016 differed significantly from observed frequencies, indicating a strong decline in E. edulis populations ( $\mathrm{p}<0.05, x_{\text {scenario } 1}^{2}=16.5^{*}$; $\left.\mathrm{p}<0.01, x_{\text {scenario } 2}^{2}=36.8^{* *}\right)($ Figure 4B).

In A1, predicted A. alexandrae population for 2010 did not differ from observed data $\left(\mathrm{p}>0.05, x_{\text {scenario } 1}=\right.$ $0.1^{\text {ns }}, x^{2}{ }_{5 \%}=19.68, x^{2}{ }_{1 \%}=24.73$ ) (Figure 4C). The 2013 scenario 1 prediction was significantly different from observed values $\left(\mathrm{p}<0.05, x_{\text {scenario } 1}^{2}=21.5^{*}\right)$, indicating strong growth (Figure 4D), scenario 2 ingrowth and mortality rates were similar to observed data $\left(\mathrm{p}>0.05, x_{\text {scenario } 2}^{2}=14.5^{\mathrm{ns}}\right)$. Under both scenarios, A. alexandrae predictions for 2016 differed from observed 2013 values ( $\mathrm{p}<0.01, x_{\text {scenario } 1}^{2}=31.8^{* *}$; $\left.\mathrm{p}<0.05, x_{\text {scenario } 2}^{2}=23.3^{*}\right)$. Projections for 2021 reinforce the possibility of $E$. edulis extinction, pointing to $E$. edulis decline (363 ind. ha-1) and A. alexandrae establishment (771 ind. ha-1).

In A2, ingrowth rate (4\%) was higher than mortality rate (2\%) for E. edulis from 2007 to 2010 . However, mortality rate (11\%) became higher than ingrowth (6\%) during 2010 2013. Projected frequencies for 2010 ( $\mathrm{p}>0.05, x_{\text {sc }}^{2}$ $\left.=0.3^{\mathrm{ns}}\right)$ and $2013\left(\mathrm{p}>0.05, x_{\text {scenario } 1}^{2}=5.5^{\mathrm{ns}}, x_{\text {scenario } 2}^{2}=\right.$ $\left.7.7^{\text {ns }}\right)$ were similar $\left(x_{5 \%}^{2}=19.91, x_{1 \%}^{2}=21.67\right)$ to observed frequencies (Figures 4E, 4F). However, when 2010-2013 mortality rates (scenario 2) were used to estimate E. edulis populations in 2016, the outcome suggested a significant reduction in numbers $\left(\mathrm{p}<0.05, x_{\text {scenario1 }}^{2}=8.1^{\mathrm{ns}}, x_{\text {scenario } 2}^{2}=\right.$ $22.62^{* *}$ ) (Figure 4F).

Revista Árvore. 2018;42(2):e420216 

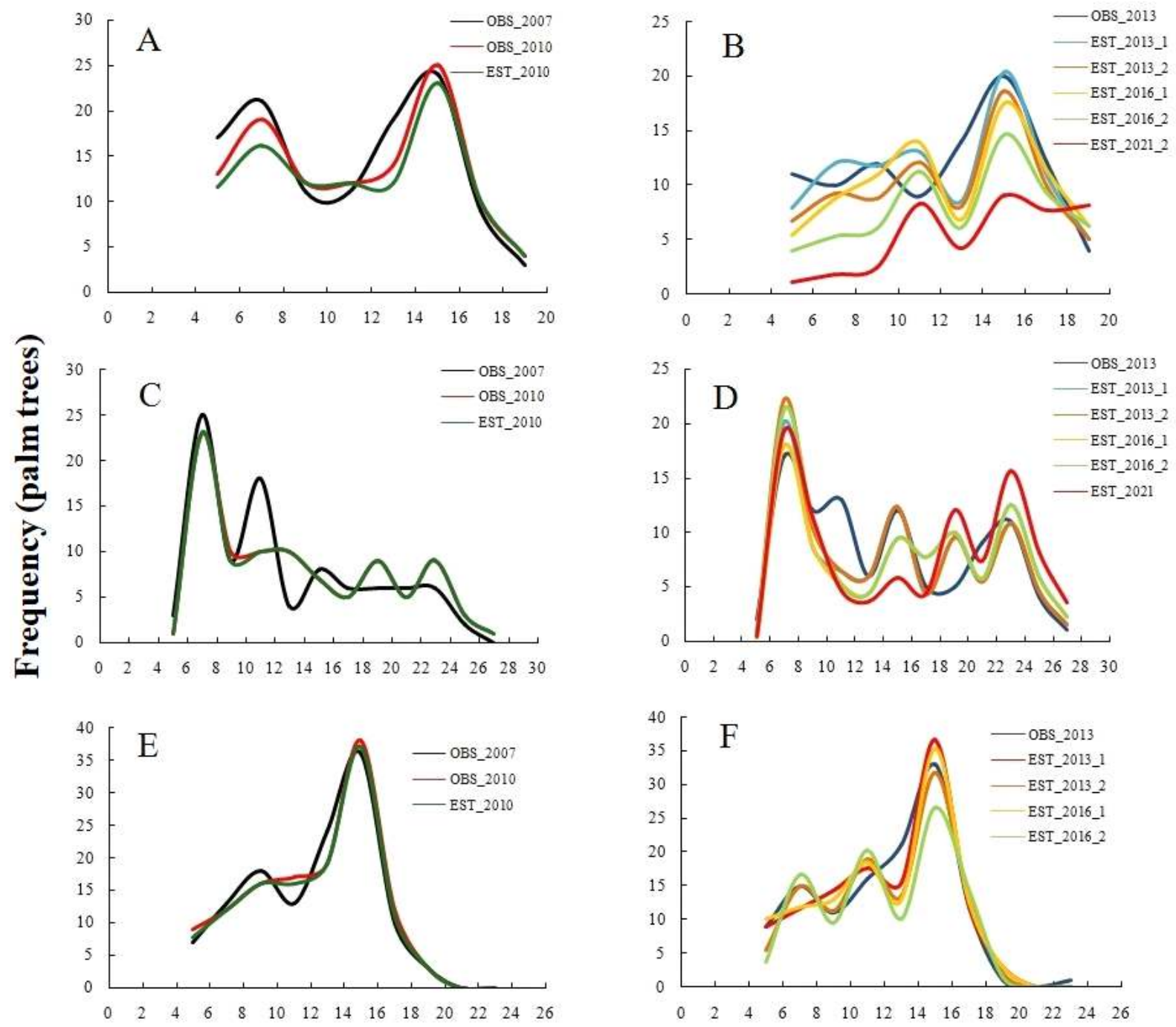

\section{$\operatorname{DBH}(\mathbf{c m})$}

Figure 4 - Observed (OBS) and estimated (EST) frequencies. A, B) Predicted E. edulis frequency in A1. C, D) Predicted A. alexandrae frequency in A1. E, F) Predicted E. edulis frequency in A2. Scenarios 1 and 2 used ingrowth and mortality rates during 2007/2010 and 2010/2013, respectively.

Figura 4 - Frequências observadas (OBS) e estimadas (EST). A, B) Prognoses de E. edulis em A1. C, D) Prognoses de A. alexandrae em A1. E, F) Prognoses de E. edulis em A2. Cenários 1 e 2 = uso de taxas de ingresso e mortalidade observadas em 2007/2010 e 2010/2013, respectivamente.

\section{DISCUSSION}

We observed natural E. edulis populations at high densities in both forest fragments (A1 $=920$ ind. ha-1; A2 = 992 ind. ha-1). By comparison, 342-366 palms ha-1 were recorded in Atlantic Forest of Eldorado do Sul,
São Paulo (Fantini and Guries, 2007). When seedlings and immature plants are included, maximum density ranges from 5,000 to 8,000 ind. ha-1 (Orlande et al., 1995). Similar to what was found in other studies (Dislich et al., 2002; Almeida et al., 2015), the three exotic palm species in A1 were probably introduced via avifauna.

Revista Árvore. 2018;42(2):e420216 
We observed high population density (776 ind. ha $^{-1}$ ) among $A$. alexandrae, with individuals concentrated in the 7-23 DBH classes. This density is associated with rapid vertical growth, leading to dominance of the LS and MS strata. These results suggest that $A$. alexandrae had already been successfully established in the past, and current populations continue to proliferate rapidly. By comparison, a high-density population of A. cunninghamiana $(\mathrm{DBH}=9.5-25 \mathrm{~cm}$ and stem height $=12 \mathrm{~m}$ ) was found in an Atlantic Forest reserve of São Paulo, Brazil (Dislich et al., 2002). The presence of this invasive species in the reserve is unlikely to be from past disturbances in fragmented forests; instead, the close proximity of afforested urban squares and gardens to forest remnants results in a continuous supply of exotic seeds via avifaunal interactions (Dislich et al., 2002; Mengardo and Pivello, 2012).

Dynamics of E. edulis in A1 reveals that natural regeneration is in progress, mainly due to the dominance of reproductive adults in the middle and superior vertical strata. However, E. edulis populations were strongly and negatively affected in plots that also contained A. alexandrae, which exhibited intense regeneration associated with large-diameter individuals. On average, each $E$. edulis adult contributes to the regeneration of 98 seedlings per year (Matos et al., 1999; Reis et al., 2000; Fantini and Guries, 2007). Therefore, E. edulis survival and growth depends strongly on seedling density and adult presence.

Several researchers had previously suggested that E. edulis regeneration would remain stable regardless of local environmental conditions (Matos et al., 1999). Our results do not support such a conclusion; reduced E. edulis regeneration in our study fragments during 2010-2013 appear to be associated with precipitation and humidity fluctuations (INMET, 2014) linked to global climate change (IPCC, 2014). Indeed, multiple studies have demonstrated that E. edulis has very specific water requirements (Reis et al., 2000; Fantini and Guries, 2007; Corrêa Júnior et al., 2008).

The continuous increase of A. alexandrae may create a genetic flow barrier among $E$. edulis populations through mechanisms such as resource competition, as well as differential pollination, seed dispersal, and seedling survival efficiency (Carvalho et al., 2015; Santos et al., 2016). In contrast to A. alexandrae success, we found a low number of $L$. chinensis seedlings, despite previous reports of high germination rate (96-99\%) regardless of soil and climatic conditions (Kobori, 2006). This outcome may be because $L$. chinensisis poorly adapted to the shaded conditions in a closed-canopy forest.

Although we did not evaluate how forest fragmentation influences growth and gene flow dynamics of palm trees (Santos et al., 2016), we note that fragmentation probably had direct and indirect effects on plant biodiversity in both study sites. Currently, the Atlantic Forest is heavily fragmented, and evidence shows that species composition responds strongly to the degree of isolation or connectivity, fragment size and shape, as well as characteristics of surrounding matrices and edges (Bierregaard Jr. et al., 1992; Brasil, 2003). Thus, monitoring and management of invasive palms among natural E. edulis populations should be based on understanding how regeneration, growth, reproduction, and mortality are associated with phenology, seed production, and dispersal.

Various methods of protection and conservation of E. edulis have been developed (Orlande et al., 1995, Martins and Lima, 1999; Reis et al., 2000; Fantini and Guries, 2007; Corrêa Júnior et al., 2008), but we have made very little progress in conserving existing populations. For conservation efforts to be effective, we need to advance public policies that focus on education, training, and environmental awareness. Specifically, people must be taught sustainable extraction techniques as well as how E. edulis production and trade relate to the species' regeneration, growth, mortality, and cutting cycle. Environmental organizations must combat illegal harvesting, foster sustainable practices, and place value on those who extract non-timber forest products in ways that preserve forest environmental services. Moreover, the government should include legislative representatives committed to nature conservation.

In agreement with Dislich et al. (2002), we recommend the partial or total removal of young and adult $A$. alexandrae, L. chinensis, and A. caudata within secondary fragments and their surroundings, thus hindering the propagation of these invasive species within forests. We also advise the enforcement of Law 11.428, which delineates the use and protection of native vegetation in the Atlantic Forest Biome (Brasil, 2006). Continued monitoring under this law should help conserve the genetic inheritance of E. edulis populations and maintain native plant biodiversity. Currently, the majority of afforestation and landscaping species are

Revista Árvore. 2018;42(2):e420216 
not screened for possible environmental damage or the potential of biological invasion. Finally, caution and careful planning must accompany any introduction of landscapes with exotic trees.

\section{CONCLUSION}

The exotic palm A. alexandrae represents a major risk to native $E$. edulis populations in the Atlantic Forest because of strong avifauna propagation, high germination rate, and dominance in the lower and middle forest vertical strata.

Natural E. edulis populations are actually viable and sustainable if communities maintain continuous gene flow through regeneration, growth, and fruiting. However, control and monitoring measures should be developed for exotic palm trees, especially in areas where A. alexandrae is already present.

Finally, planning of afforestation and landscaping projects near Atlantic Forest remnants should carefully consider whether selected plants have invasive potential that could harm native plant biodiversity.

\section{ACKNOWLEDGEMENTS}

We thank the Department of Forestry Engineering (DEF/UFV), Botany Herbarium of the Federal University of Viçosa (UFV), and DAP Engenharia Florestal Ltda. We thank Suwa Rempei (Forestry and Forest Products Research Institute) and all those who contributed to this research.

\section{REFERENCES}

Almeida WR, Lopes AV, Tabarelli M, Leal IR. The alien flora of Brazilian Caatinga: deliberate introductions expand the contingent of potential. Biological Invasions. 2015;17:51-56.

Araujo JSP, Silva AMS. A palmeira imperial: da introdução no Brasil-Colônia às doenças e pragas no século XXI. Ciência e Cultura. 2010;62(1):26-8.

Asner GP, Knapp DE, Broadbent EM, Oliveira PJC, Keller M, Silva JM. Selective logging in the Brazilian Amazon. Science. 2005;310:480-2.

Brasil. Ministério do Meio Ambiente. Fragmentação de ecossistemas - causas, efeitos sobre a biodiversidade e recomendações de políticas públicas. Brasília, DF: MMA/SFB; 2003. [acesso em fev. de 2015]. Disponível em: http:// www.mma.gov.br/estruturas/chm/_arquivos/ fragment.pdf.

Brasil. Presidência da República. Lei no 11.428 de 22 de Dezembro de 2006. Lei de utilização e proteção da vegetação nativa do Bioma Mata Atlântica. [acesso em fev. de 2014]. Disponível em: http://www.planalto.gov.br/ccivil_03/_ato20042006/2006/lei/l11428.htm.

Bierregaard Jr. RO, Lovejoy TE, Kapos V, Santos AA, Hutchings RW. The biological dynamics of tropical rainforest fragments. BioScience. 1992;42:859-66.

Buongiorno J, Michie BR. A matrix model of unevenaged forest management. Forest Science. 1980;26(4):609-25.

Carvalho CS, Ribeiro MC, Côrtes MC, Galetti M, Collevatti RG. Contemporary and historical factors influence differently genetic differentiation and diversity in a tropical palm. Heredity. 2015;115(3):216-24.

Cervi CE. O mercado do palmito. Relatório para o conselho Britânico. 1996. v.34. (não publicado)

Chapple DG, Simmonds SM, Wong BBM. Can behavioral and personality traits influence the success of unintentional species introductions? Trends in Ecology \& Evolution. 2012;27:57-64.

Chediack SE, Baqueiro MF. Extração e conservação do palmito. In: Galindo-Leal C, Câmara IG editores. State of the Hotpots: Mata Atlântica - Biodiversidade, Ameaças e Perspectivas. Bela Vista: Fundação SOS Mata Atlântica; 2005. p.406-412.

Christianini AV. Fecundidade, dispersão e predação de sementes de Archontophoenix cunninghamiana $\mathrm{H}$. Wendl. \& Drude, uma palmeira invasora da Mata Atlântica. Revista Brasileira de Botânica. 2006;29(4):587-94.

Cincotta RP, Wisnewski J, Engelman R. Human population in the biodiversity hotspots. Nature. 2000;404:990-2.

Condé TM, Tonini H. Fitossociologia de uma

Revista Árvore. 2018;42(2):e420216 
Floresta Ombrófila Densa na Amazônia Setentrional, Roraima, Brasil. Acta Amazonica. 2013;43(3):247-60.

D’Antonio CM, Vitousek PM. Biological invasions by exotic grasses, the grass/fire cycle, and global change. Annual Review of Ecology and Systematics. 1992;23:63-87.

Dislich R, Kisser N, Pivello R. A invasão de um fragmento florestal em São Paulo (SP) pela palmeira australiana Archontophoenix cunninghamiana H. Wendl. \& Drude. Revista Brasileira de Botânica. 2002;25(1):55-64.

Fantini AC, Guries RP. Forest structure and productivity of palmiteiro (Euterpe edulis Martius) in the Brazilian Mata Atlântica. Forest Ecology and Management. 2007;242:185-94.

Galetti M, Fernandez JC. Palm heart harvesting in the Brazilian Atlantic forest: changes in industry structure and the illegal trade. Journal of Applied and Ecology. 1998;35:294-301.

Gastauer M, Sobral MEG, Meira-Neto JAA. Preservation of primary forest characteristics despite fragmentation and isolation in a forest remnant from Viçosa, MG, Brazil. Revista Árvore. 2015;39(6):985-94.

Instituto Nacional de Meteorologia do Brasil INMET. Monitoramento climático. [acesso em jun de 2014]. Disponível em: http://www.inmet.gov.br/.

Intergovernmental Panel on Climate Change - IPCC. Climate Change 2014 Synthesis Report Summary for Policymakers. [accessed on Aug. 2015]. Avaiable em: http://www.ipcc.ch.

Corrêa Júnior C, Bellettini S, Santos AF, Neves EJM, Chaimsohn FP, Rodigheri HR. Cultivo da Juçara para Produção de Palmito. In: Santos AF, Corrêa Júnior C, Neves EJM. editores. Palmeiras para Produção de Palmito: Juçara, Pupunheira e Palmeira Real. Colombo: Embrapa Florestas; 2008. p.23-37.

Ferreira Júnior WG, Silva AF, Meira-Neto JAA, Schaefer CEGR, Dias AS, Ignácio M, et al. Composição florística da vegetação arbórea de um trecho de Floresta Estacional Semidecídua em Viçosa, Minas Gerais, e espécies de maior ocorrência na Região. Revista Árvore. 2007;31(6):1121-30.
Kobori NN. Germinação de sementes de Livistona chinensis (Jack.) R. Br. ex. Mart. (Arecaceae) [dissertação]. Jaboticabal: Faculdade de Ciências Agrárias e Veterinárias; 2006.

Martins SV, Lima DG. Cultura de palmeiras I: palmiteiro (Euterpe edulis Martius). Viçosa, MG: UFV; 1999.

Matos DMS, Freckleton RP, Watkinson AR. The role of density dependence in the population dynamics of a tropical Palm. Ecology. 1999;80(8):2635-50.

Mengardo AL, Pivello R. Phenology and fruit traits of Archontophoenix

cunninghamiana, an invasive palm tree in the Atlantic forest of Brazil. Ecotropica. 2012;18:45-54.

Orlande T, Laarman J, Mortimer J. Palmito sustainability and economics in Brazil's Atlantic coastal forest. Forest Ecology and Management. 1995;80:257-65.

Parker IM, Simberloff D, Lonsdale WM, Goodell K, Wonham M, Kareiva PM et al. Impact: toward a framework for understanding the ecological effects of invaders. Biological Invasions. 1999;(1):3-19.

R Core Team. R: A language and environment for statistical computing. [accessed at: Feb. 2018]. Avaiable on: http://www.R-project.org/.

Reis MS, Fantini AC, Nodari RO, Reis A, Guerra MP, Mantovani A. Management and conservation of natural populations in Atlantic Rain Forest: the case study of Palm Heart (Euterpe edulis Martius). Biotropica. 2000;32(4):894-902.

Santos AS, Cazetta E, Dodonov P, Faria D, Gaiotto FA. Landscape-scale deforestation decreases gene flow distance of a keystone tropical palm, Euterpe edulis Mart (Arecaceae). Ecology and Evololution. 2016;6(18):6586-98.

Soares-Filho BS, Rajão R, Macedo M, Carneiro A, Costa W, Coe M, et al. Cracking Brazil's Forest Code. Science. 2014;344:363-4.

SOS Mata Atlântica Foundation/Instituto Nacional de Pesquisas Espaciais - SOSMA/INPE. Área remanescente de Mata Atlântica. 2014.

Revista Árvore. 2018;42(2):e420216 
[acesso em: fev. 2016]. Disponível em: http:// www.inpe.br/noticias/

noticia.php?Cod_Noticia=3610.

Souza AL, Soares CPB. Florestas nativas - estrutura, dinâmica e manejo. Viçosa, MG: UFV; 2013.

van Wilgen BW, Richardson DM. Challenges and trade-offs in the management of invasive alien trees. Biological Invasions. 2014;16:721-34.

Revista Árvore. 2018;42(2):e420216 